\title{
En torno al concepto de «cine nacional» El caso de «la nueva ola del cine rumano»
}

\author{
Francisco M. Ayuso Ros
}

Recibido: 13.04.2021 — Aceptado: 01.06.2021

\section{Título / Titre / Titolo}

Sur le concept de «cinéma national». Le cas de «la nouvelle vague du cinéma roumain»

On the concept of «national cinema». The case of «the new wave of Romanian cinema»

Sul concetto di «cinema nazionale». Il caso della «new wave del cinema rumeno»

\section{Resumen / Résumé / Abstract / Riassunto}

El presente trabajo de investigación se centra en estudiar un fenómeno cinematográfico que fue adquiriendo un cariz propio en el circuito de festivales de cine europeos, en especial en el Festival de Cannes, asî como en la prensa especializada, y que se vino a llamar la «Nueva ola del cine rumano». Nuestro punto de partida es asumir que conceptos como «cine nacional» $\mathrm{y}$ «nueva ola» requieren pensarse en el marco de un mundo globalizado, tomando como referente principal el contexto europeo de la primera década del siglo XXI, así como el rol que tanto los festivales de cine como los diferentes mecanismos de financiación europeos juegan en la configuración de las tendencias cinematográficas que ocupan el primer plano de la actualidad. De igual forma, consideramos necesario analizar la posible cohesión de esta marca común aplicando el bisturí metodológico del análisis textual.

Le présent travail de recherche se concentre sur l'étude d'un phénomène cinématographique qui était en train d'acquérir un caractère propre dans le circuit des festivals de films européens, notamment au Festival de Cannes, ainsi que dans la presse spécialisée, et qui a été appelé la «Nouvelle vague du cinéma roumain». Notre point de départ est de supposer que des concepts tels que «cinéma national» et «nouvelle vague» doivent être pensés dans le cadre d'un monde globalisé, en prenant comme référence principale le contexte européen de la première décennie du 21ème siècle, ainsi que le rôle que les festivals de films et les différents mécanismes de financement européens jouent dans la configuration des tendances cinématographiques qui sont actuellement au premier plan. De même, nous estimons nécessaire d'analyser la cohésion éventuelle de cette marque commune en appliquant le scalpel méthodologique de l'analyse textuelle.
The article focuses on the study of a cinematographic phenomenon that has gradually acquired its own identity in the circuit of European film festivals, especially the Cannes Festival, as well as in the specialised press, and has come to be known as «Romanian new wave cinema». Our starting point is to consider concepts such as «national cinema» and «new wave» as in need to be accounted for in the framework of a globalised world and of 21 th century Europe, while taking into account the role played by film festivals and different European funding mechanisms in configuring the trends which have recently come to the fore. We also deem necessary to analyse the supposed cohesion of the common brand of Romanian film production by applying the methodological scalpel of textual analysis.

L'articolo centra l'attenzione critica sullo studio di un fenomeno cinematografico che ha acquisito un carattere proprio nel circuito dei festival cinematografici europei, specialmente nel Festival di Cannes, così come nella stampa specializzata, e che è stato denominato la «new wave del cinema rumeno». Il nostro punto di partenza è l'idea che concetti come «cinema nazionale» e «new wave» devono essere pensati nel quadro di un mondo globalizzato, in special modo in rapporto con il contesto europeo della prima decade del XXI secolo, e prendendo in considerazione il ruolo che tanto i festival cinematografici quanto i diversi meccanismi di finanziamento europei giocano nella configurazione delle tendenze cinematografiche attualmente in primo piano. Consideriamo altrettanto necessario analizzare la possibile coesione di questo marchio comune mediante l'uso del bisturi metodologico dell'analisi testuale.

\section{Palabras clave / Mots-clé / Key words I Parole chiave}

Cine rumano, nueva ola, cine nacional, análisis textual, festivales de cine.

Cinéma de Roumanie, nouvelle vague, film national, analyse textuelle, festivals de cinéma.

Romanian cinema, new wave, national cinema, textual analysis, film festivals.

Cinema rumeno, new wave, cinema nazionale, analisi testuale, festival di cinema. 


\section{Introducción}

La «Nueva ola del cine rumano» es un fenómeno cinematográfico que fue tomando forma en los principales festivales de cine europeos a lo largo de la primera década del siglo XX, y que llegó a consolidarse en los medios especializados de todo el mundo sobre todo a partir del año 2008. En este artículo nos proponemos analizar este movimiento cinematográfico, con el fin de dilucidar si se dan o no una serie de rasgos estilísticos y narratológicos compartidos entre las obras que se incluyen en el mismo, tomando en consideración los conceptos que se ven implicados en dicha consideración, como son los de «nueva ola»y «cine nacional», así como el rol que juegan los festivales de cine en la certificación de las nuevas olas cinematográficas. Para ello, fijaremos como ejes constitutivos de nuestro trabajo las producciones de los tres realizadores más relevantes de este cine: Cristi Puiu, Cristian Mungiu y Corneliu Porumboiu, en el arco temporal que abarca de 2001 a $2010^{1}$.

El cine rumano se convirtió en el foco de atención internacional cuando el Festival de Cannes de 2005 concedió al film La muerte del señor Lazarescu (Moartea domnului Lazarescu, Cristi Puiu, 2005) el premio a la mejor película en la sección Un Certain Regard. A partir de este momento los focos de la crítica internacional se dirigieron hacia la industria cinematográfica de Rumanía, un país en el que la producción de películas estaba sumida en la decadencia desde que en 1989 una revolución ciudadana pusiera fin a la dictadura comunista. El cine de socialismo de estado (1948-1989), que rendía culto a la personalidad del dictador Nicolae Ceausescu, había dejado paso, en la década de los 90, a un cine «miserabilista» que, liberado de la censura, se había llenado de escenas gratuitas de sexo, de violencia, de lenguaje grotesco y parábolas políticas que evidenciaban un vacío de identidad (Pop, 2014, 57). Al mismo tiempo, algunos

Este artículo parte de una investigación más extensa, que tomó forma en la tesis doctoral La puesta en crisis de la realidad. Política y modos de representación en los nuevos cines en Europa: el caso de "La nueva ola del cine rumano» (2001-2010), dirigida por la profesora Giulia Colaizzi en la Universitat de València. autores se habían refugiado en un «realismo simbólico» que evitaba toda referencia a la realidad social en favor de lograr una belleza estética (ib.: 95). Este declive había hecho mella en el ámbito de la exhibición: de las 320 salas de cine del año 1989 se había pasado a las 85 del año 2005. De ahí que, en un país de alrededor de 22 millones de habitantes, el año en que se estrenó La muerte del señor Lazarescu el acceso al cine en Rumanía estaba restringido a los grandes centros urbanos.

Dado que Rumanía carecía de infraestructura suficiente para producir, distribuir y exhibir su cine más allá de sus fronteras, el único canal viable era el circuito de festivales internacionales. La muerte del señor Lazarescu fue la primera película rumana en distribuirse a nivel internacional, y fue la encargada de abrir el camino a toda una serie de estrenos que darían empuje a esta nueva corriente cinematográfica. Una «nueva ola» que iba a acaparar galardones en los principales festivales de cine de todo el mundo en los siguientes años, pero que ya había dejado su impronta en los años precedentes en una categoría menor. Cuando en enero de 2008 el crítico de cine de The New York Times titula su artículo «In film, the Romanian new wave has arrived» (Scott, 2008a), la segunda película de Puiu encabeza el repaso de esta «nueva ola». Dos meses más tarde, el crítico de cine del periódico The Guardian, Ronald Bergan, publicaba la crónica de unas jornadas celebradas en Bucarest a las que había sido invitado bajo el título «Romanian Films Today», en la que comenzaba con la siguiente aseveración: «The Death of Mr. Lazarescu launched the 'Romanian new wave'» (2008).

Un año antes de que su segundo largometraje se convirtiera en la película seminal de este creciente interés por el cine rumano, Cristi Puiu se había alzado con el Oso de Oro al mejor cortometraje con Cigarettes and Coffe (Un cartus de Kent si un pachet de cafea, 2004). Ese mismo año el corto The Apartment (Apartamentul, Constantin Popescu, 2004) lograría el mismo galardón en el Festival de Venecia, mientras que Traffic (Trafic, Catalin Mitulescu, 2004) consiguió la Palma de Oro al mejor cortometraje en el Festival de Cannes 2004, si bien la fecha inicial de esta renovación de la cinematografía rumana hay que si- 
tuarla en 2001, año de producción de Bienes y dinero (Marfa si banii), primer largometraje de Puiu.

La Cámera d'Or de Cannes a 12:08 al este de Bucarest ( $A$ fost sau n-a fost?, Corneliu Porumboiu, 2006) y la Palma de Oro en el mismo festival en 2007, acompañada del reconocimiento internacional de 4 meses, 3 semanasy 2 días (4 Luni, 3 saptamani si 2 zile, Cristian Mungiu, 2007), ratificaron el atractivo que esta joven generación de cineastas rumanos suscitaba tanto en la crítica especializada como en los festivales internacionales. Sin embargo, los directores aludidos no se reconocían en una marca que los englobaba en una práctica común. Para Cristian Mungiu, todo se reduce a «una etiqueta. No hay un plan ni un manifiesto, solo una serie de directores de edad similar que nos expresamos a la vez y que reaccionamos contra el tipo de cine que se hacía en Rumanía a finales de los 80 y principios de los 90. Nada más» (Salvà, 2010). Cristi Puiu lo expresa de forma similar (Sardá, 2012).

Así pues, el interés por este «movimiento» ha circulado paralelo a su cuestionamiento como tal. Eulàlia Iglesias se sumaba a esta cuestión introduciendo en el debate el papel que juegan los festivales de cine: «¿Existe una explosión del cine rumano? ¿O se trata de una de estas modas que se dan en los festivales, aficionados a encumbrar periódicamente alguna cinematografía hasta entonces ignota?» (25). En el periódico The New York Times se lanzaba una pregunta similar: «Is there or is there not a Romanian new wave?» (Scott, 2008a). Una cuestión que se repite en los análisis científicos sobre este tema: «Is it or is it not a «New Wave?» (Pop, 2010, 20). Todos estos interrogantes sitúan el foco de atención en la confluencia, o falta de ella, de unos rasgos formales y argumentales comunes a todas estas películas, así como en dilucidar si los cineastas incluidos en este movimiento comparten unas motivaciones artísticas y unas preocupaciones sociales afines. Existe una coincidencia general en los estudios realizados al respecto -baste señalar los dos más extensos y representativos (Pop, 2014; Nasta, 2013) - en destacar una serie de conceptos que se repiten: realismo, naturalismo, ausencia de música extradiegética, sobriedad interpretativa, humor negro, teatro del absurdo, planos secuencia largos, neorrealismo, los nuevos cines de los años 60, ruptura formal, cámara al hombro, etc. Por su parte, el crítico de cine Andrei Gorzo considera relevante «una intención tremenda y especial por buscar la verdad», de modo que estaríamos ante un cine que, aunque parte de «una problemática profundamente local, a través de la pasión por la búsqueda de la verdad, llegan a algo universal». Gorzo no duda en señalar los referentes de este cine en «el neorrealismo italiano de posguerra, el Cinéma veritè que intentaron los directores de la Nouvelle vague, así como con los cineastas norteamericanos de los 6070». Un cine, por tanto, en el que las fronteras entre la ficción y el documental quedarían desdibujadas. Gorzo habla de «películas de ficción que cultivan el documental» y de una «preocupación común por no manipular al espectador» (Istambul, Martínez, 2008).

A su vez, la consideración de «nuevo cine» que recibe esta eclosión cinematográfica guarda relación con los movimientos artísticos conocidos como los Nuevos cines, que surgieron a finales de los años cincuenta y principios de los sesenta como reacción a una experiencia social traumática o a un estado de cosas que se pretendía cambiar. Este fenómeno, que alcanzó una dimensión mundial, supuso una amplia y heterogénea galaxia de nuevas propuestas fílmicas como portadoras de imágenes, formas de hacer, modelos industriales y códigos lingüísticos que abrieron la puerta a la modernidad en la Historia del Cine. Es decir, nuevas técnicas y nuevas formas estéticas, nuevas maneras de relacionarse con la realidad, nuevas miradas sobre las respectivas sociedades en las que nacen, nuevas generaciones de creadores y profesionales, nuevos discursos y nuevos conceptos cimentan la irrupción de una clara conciencia reflexiva sobre el hecho cinematográfico y sobre la propia práctica del cine. Estos «nuevos cines» se dieron en España, Brasil, Argentina, Gran Bretaña, Polonia, República Checa o Hungría. Las circunstancias históricas, el dilatado régimen dictatorial de Nicolae Ceausescu y la difícil situación económica que siguió a su caída, han determinado que la eclosión de esta nueva cinematografía haya coincidido con la incorporación de Rumanía a la Comunidad Económica Europea, el 1 de enero de 2007. 


\section{Marco teórico y metodológico}

Tomando como punto de partida que lo real como tal resulta inaprensible y que únicamente podemos trazar vías de acceso al mismo mediante procesos de mediación, asumimos que el concepto de realismo, en cuanto sistema relacional entre el objeto artístico y el mundo, no supone una traslación directa y espontánea de unos procesos históricos de una realidad concreta a un marco textual, sino un conjunto de estrategias formales que proponen una relación con el mundo en la que sea factible identificar las huellas de lo real. Esas huellas nos llegan a través de representaciones que se inscriben en un sistema relacional, en el que los objetos artísticos suponen la representación de una representación previa (Colaizzi, 2007).

De acuerdo con estas consideraciones, en nuestra investigación llevaremos a cabo un análisis fílmico de acuerdo con los procesos expuestos por Casetti y Di Chio (1994): descomposición, recomposición e interpretación. Este análisis textual, que se enmarca en la semiótica fílmica, profundiza en aquellos recursos asociados a la estructura del relato y la construcción de personajes, así como el análisis de los procesos de significación formales: planos, tipos de encuadre, iluminación, sonido, movimientos de cámara y sintaxis fílmica. Además, prestaremos especial atención en nuestro análisis al papel asignado al espectador en la representación.

La formalización práctica de los diferentes modos de representación implica la creación de toda una serie de propuestas discursivas en las que se produce la selección, la ordenación y la jerarquización de diferentes elementos de la realidad en base a unos determinados criterios valorativos. Asimismo, y atendiendo a la dimensión industrial de la que participan, estos mecanismos representacionales movilizan sistemas de representación que interactúan con el orden político-social en el que se insertan y participan de la conformación de una diversidad de órdenes del saber que estructuran el conocimiento en un espacio determinado. Es en virtud de esta relación entre las prácticas discursivas y la producción de conocimien- to, siempre en correlación con las estructuras de poder que los determinan, que se dan en un espacio organizado socialmente, que consideramos conveniente introducir la noción de dispositivo en nuestro trabajo.

Este concepto, de carácter polivalente y dúctil, se ha venido empleando en diversos campos de la sociología (como la ciencia o el trabajo), la pedagogía, el derecho o la filosofía. En el ámbito de los medios de comunicación, Pierre Shaeffer describió la relación entre los responsables de la comunicación y los receptores como un «dispositif stratégique» (61); mientras que en el estudio del medio cinematográfico sería Jean-Louis Baudry quien recurriera al término para referir la proyección cinematográfica, incluyendo al sujeto que asiste a la misma (58).

El origen del empleo teórico del término hay que situarlo en los estudios filosóficos de Michel Foucault, quien en 1975 hizo referencia al dispositivo disciplinario en el libro Vigilar y castigar. La noción de dispositivo se inserta en la reflexión filosófica de Foucault como un intento de articular una respuesta a las preocupaciones derivadas de las conexiones que observa entre las relaciones de poder y la producción de conocimiento. Tomando distancia respecto de los planteamientos positivistas, cuestiona las visiones que entienden la historia oficial desde las relaciones de causa-efecto que se establecen entre los hechos, los cuales son presentados según un orden que responde a criterios racionales. De acuerdo con la definición que el filósofo francés aporta de este concepto (en Agamben, 250), el dispositivo destaca por la heterogeneidad de elementos que se disponen en una red dinámica que varía en función de la efectividad lograda en una situación específica. Esta capacidad mutable implica tanto a los elementos que refieren lo que se dice como a aquellos que se sitúan del lado de lo no dicho, y todo ello inserto en un juego de relaciones de poder. En consecuencia, este dispositivo es capaz de dar respuesta a una problemática histórica concreta potenciando o bloqueando determinadas relaciones de fuerza, lo que tiene efectos en el ámbito del saber. Su función no responde a las órdenes concretas de una instancia de poder, sino que responde a una es- 
trategia que es el resultado de las relaciones que se dan en el mismo en una coyuntura determinada (Foucault, 1991, 127-130). Es a través de estas estrategias que el dispositivo incide en lo real, aplicándose en un conjunto de elementos y logrando efectos concretos.

\section{Sobre las implicaciones de los términos unueva olan y rcine nacionaln}

La expresión Nouvelle Vague fue acuñada por Françoise Giroud a finales de 1957 con motivo de una encuesta de investigación, lanzada por el semanario L'Express, para categorizar a una nueva generación. Este término designó a una generación, nacida antes de la Segunda Guerra Mundial, como un fenómeno sociológico por derecho propio. En el terreno cinematográfico, terminó dando forma a un grupo de cineastas que compartían unas inquietudes comunes y unos planteamientos estéticos similares. Sin embargo, tampoco los cineastas franceses incluidos en dicha corriente cinematográfica compartían un sentimiento de pertenencia común. Jean-Luc Godard situalba el origen de la Nouvelle $V a$ gue en «los cineclubs, la Cinémathèque y también en un cierto pensamiento crítico cuya figura principal fue, sin duda, André Bazin»; mientras que para Claude Chabrol el término no dejaba de ser una etiqueta: «En 1958 y 1959, cuando los compañeros de los Cahiers y yo pasamos a la realización, fuimos promocionados como una marca de jabones» (Fecé, 45).

En un artículo publicado en 1959, Noël Burch rebajaba el significado social y político del término «nueva ola» y hablaba de un «fenómeno comercial» que se había producido en la «bolsa de valores de Cannes». La calificaba de una «school within a school», dado que la actitud de los miembros hacia el cine se había fraguado en la revista Cabiers du Cinéma. Burch destaca algunas particularidades a tener en cuenta: la decadencia del modelo de cine anterior; el bajo coste de las producciones de esta nueva ola; el éxito de las películas, tanto dentro como fuera del país; una preocupa- ción por la dimensión moral de los temas o un cierto formalismo (Burch, 1959: 16-18).

$\mathrm{Al}$ igual que ocurría en otras cinematografías, bajo el paraguas de dicha etiqueta destacaban las singularidades de cada realizador, de tal manera que son las renuncias (a los esquemas narrativos hegemónicos o a los grandes temas argumentales) el principal nexo de unión (Pérez, 178-179); si bien podemos añadir otros como un sustrato teórico común, la influencia de la teoría de la «política de los autores» o el modo en que las reivindicaciones sociales de la juventud se traducían en una mayor libertad creativa. En opinión de Michel Marie, la Nouvelle Vague supuso «una de las escuelas más coherentes de la historia del cine», entendiendo por escuela «una mínima doctrina crítica, compartida por un grupo de periodistas o de cineastas; un programa estético que suponga una estrategia; la publicación de un manifiesto que explicite esa doctrina...» (Fecé, 45-46). Sin embargo, a diferencia del Free Cinema inglés, no todos los nuevos cines tenían un manifiesto común.

\subsection{El cine rumano en los nuevos cines de los años 60}

Tras la designación de Nicolae Ceausescu como Secretario general en 1965, se sucedió un corto período de florecimiento económico y un deshielo en todas aquellas cuestiones que afectaban a la vida cultural, y que se extendió hasta 1971 (Nasta, 2013, 18-19). En tales circunstancias, únicamente un puñado de películas van a presentar una alternativa al realismo socialista y a las epopeyas históricas de corte nacionalista (cuyo máximo representante es el realizador Sergiu Nicolaescu), y que suponen la aportación rumana a la corriente de los nuevos cines de las repúblicas soviéticas.

Cuando se estudia este grupo de películas, se suelen destacar únicamente dos nombres, los de los realizadores Lucian Pintilie y Liviu Ciulei. Así ocurre con el libro dedicado a los nuevos cines de los países del Este coordinado por Carlos Losilla y José Enrique Monterde (2006) o con la monografía publicada por Doru Pop (2014). La investigadora 
Dominique Nasta amplía el espectro con la obra de Mircea Muresan, Mircea Saucan, Andrei Blaier, Lucian Bratu y Malvina Ursianu. Tal como hemos desarrollado en la tesis doctoral (Ayuso Ros, 2021), en estas películas se aprecia la influencia de obras representativas de la Nouvelle Vague, de las primeras películas de Michelangelo Antonioni o del cine del cine del realizador húngaro Miklós Jancsó. Esta asimilación de las nuevas tendencias del cine europeo era reconocida por la principal revista cinematográfica de la época en Rumanía, Cinema (Pop, 2014, 20). La película que abandera esta primera ola rumana es La reconstrucción (Reconstituirea, Lucian Pintilie, 1968), la cual construye una compleja alegoría sobre el poder y sus medios de adoctrinamiento, en la que el discurso oficial redefine los hechos poniendo en marcha una representación edificante al estilo realista. Dicha representación nos es mostrada por medio de una puesta en escena que la deconstruye, en un ejercicio metacinematográfico, siguiendo unas estrategias formales que evidencian el dispositivo al tiempo que plantean una reflexión acerca del medio cinematográfico, las condiciones de producción y su relación con las estructuras de poder.

Sin embargo, a diferencia de lo ocurrido con otras nuevas olas coetáneas, como la nueva ola checa, la Nova $V$ Iná -que en 1966 obtuvo 26 premios internacionales para sus largometrajes y un gran número de premios para sus cortometrajes-, este grupo de películas apenas contó con el respaldo de los festivales de cine internacionales. Lo que nos lleva a la siguiente cuestión: el papel de los festivales de cine en la configuración y consolidación de las nuevas olas cinematográficas.

\subsection{Festivales de cine: promoción, circuito alternativo y configuración de nuevas corrientes}

El papel de los festivales de cine como medios de difusión de corrientes renovadoras del cine, de articulador de contextos culturales diversos, procedentes de cinematografías alternativas, de altavoz de reivindicaciones políticas o de constructor de audiencias cubre un amplio y complejo espectro de la evolución del cine que, desde hace unos años, está ocupando una parte relevante de la historiografía académica de los estudios fílmicos, tomando en cuenta que los investigadores occidentales tienen acceso a las obras procedentes de industrias de otras partes del mundo gracias a las competiciones internacionales (Stringer, 135).

En su extenso estudio sobre cine europeo, Thomas Elsaesser (2005) dedica un apartado al estudio de los festivales de cine, a los que considera una red y una fuerza clave en el negocio del cine, que influyen en cuestiones relacionadas con la autoría, la producción, la exhibición o la cohesión de corrientes de cine nacionales, a las que otorga una dimensión europea y les ayuda a participar en las economías simbólicas globales. El autor considera que, en la esfera de los festivales de cine europeo, las nociones de arte, cine nacional y de autor son los principios rectores, a la vez que suponen un circuito alternativo a la influencia global ejercida por el cine de Hollywood. Al respecto, cabe añadir que los festivales han incorporado secciones paralelas destinadas a fomentar los contactos entre profesionales: las ferias industriales, como el Marché du film de Cannes; las plataformas de financiación y coproducción destinadas a promover proyectos de cinematografías con una industria deficiente, como el Hubert Bals Fund de Rotterdam o el IDFA Bertha Fund; el Fonds Sud Cinéma, un fondo de ayuda al cine de Latinoamérica; o los talleres de desarrollo de proyectos como el IDFA Workshop, la Cinéfondation de Cannes o el Berlinale Talent Campus, que ofrece una residencia colaborativa para el desarrollo de proyectos. Todas estas iniciativas se benefician del programa MEDIA de la Unión Europea, creado en 1991, y destinado a promover y fomentar el desarrollo de iniciativas audiovisuales a nivel europeo.

Todas estas circunstancias llevan a repensar el concepto de «nacional» aplicado a una cinematografía, pues, como explica Jaime Pena, probablemente quede muy poco de «aquel concepto que, además de una renovación generacional y estética, supuso una indudable apertura hacia territorios hasta aquel momento vírgenes en el panorama cinematográfico mundial», si bien no «podemos dar por muerto un término que renace cada 
cierto tiempo». En los festivales de cine las películas se presentan asociadas al nombre del realizador seguido del «pabellón» nacional, con lo que portar el rango de «nuevo cine» resulta muy productivo «si pretendemos lanzarnos a la conquista de los grandes festivales internacionales» (12). De esta manera, los festivales de cine, sobre todo los tres europeos más relevantes, se convierten en circuito alternativo a las salas comerciales para aquellas obras más arriesgadas, así como plataforma de lanzamiento para el cine procedente de países con una industria más débil o desconocida, dentro de una maquinaria que precisa de una novedad llamativa cada cierto tiempo.

\subsection{Los cines nacionales entre las corrientes de los flujos transnacionales}

El fenómeno de la globalización, que comprende mayoritariamente la liberalización de los mercados financieros acorde con la expansión totalizadora del capitalismo, así como la pérdida por parte de las naciones del control de los flujos productivos en favor de las corporaciones internacionales, que se benefician de las políticas desreguladoras, ha obligado a repensar las cuestiones que afectan tanto a lo social y político, como a la esfera de los fenómenos culturales. El cine es uno de ellos. Esta mayor circulación de los productos culturares, unida al carácter internacional de los festivales de cine, las coproducciones, los fondos de ayuda, el acceso a los contenidos que ofrecen las nuevas tecnologías o el auge de las plataformas digitales han dado lugar a flujos de sistemas simbólicos en los que las particularidades locales se cruzan con lo universal.

Todas estas circunstancias han llevado a que, tanto desde la crítica como desde los estudios académicos, se replantee la conveniencia del concepto de «cine nacional» y de los parámetros en los cuales puede ofrecerse todavía como herramienta teórica. El paso de los años parece haber demostrado que tras el fenómeno colectivo acaban destacando algunos nombres. Elsaesser pone el ejemplo de un equipo de fútbol que jugara bajo la camiseta de «international art cinema», el cual podría estar compuesto por jugadores de diferentes tradiciones culturales, como Zhang Yimou, Kim-Ki-duk, Quentin Tarantino, Paul Thomas Anderson o Fatih Akin (498); y hay quien se pregunta si «en lugar de hablar de un 'nuevo cine rumano’ cabría preguntarse si no sería más apropiado privilegiar el nombre de tres directores, Cristi Puiu, Corneliu Porumboiu y Cristian Mungiu» (Pena, 13).

El término «cine nacional» supone un concepto permeable, con unas fronteras difusas, y cuyo significado ha ido readaptándose a lo largo del tiempo. Su sentido se refuerza cuando se constituye en la manifestación artística e ideológica de las transformaciones sociales y políticas de una determinada sociedad, como era el caso de muchos de los nuevos cines de los años sesenta, como los países del Este que hemos señalado, o como el caso de Brasil o España; pero, la noción va perdiendo consistencia a medida que el fenómeno de la globalización se va afianzando. El cine rumano que analizamos se sitúa en esta intersección, dado que se constituye en la respuesta cinematográfica a la compleja transformación que vive el país, al tiempo que se enmarca en los flujos transnacionales del cine a nivel mundial.

De ahí que se vuelva necesario articular unas herramientas teóricas que ayuden a pensar este concepto. En un artículo de 1989 titulado «The Concept of National Cinema», Andrew Higson ofrece unas claves para comprender algunas de las implicaciones que conlleva el uso de este término en relación al cine, y para ello distingue entre cuatro criterios. En primer lugar, se situaría una aproximación económica al término en relación a la industria cinematográfica del país en cuestión, así como a los diferentes medios de financiación. En segundo lugar, están los aspectos relacionados con el público potencial que ve estas películas, de forma que se pueda dar una cierta identidad nacional compartida. El tercer criterio refiere el enfoque que de este cine se proyecta desde la crítica y su capacidad para conectar con los deseos y las fantasías del público popular. El cuarto criterio hace referencia a la posible identificación de unos rasgos textuales comunes, los temas tratados o la posibilidad de cuestionar o construir una noción de nacionalidad tanto en los textos como en la conciencia del espectador. 
A continuación, desarrollaremos un estudio de la dimensión nacional de la «nueva ola del cine rumano», tomando en consideración los cuatro criterios propuestos por Higson.

El grupo de cineastas rumanos que componen la primera «oleada» del nuevo cine rumano también pertenecen a una misma generación: Cristi Puiu (1967), Cristian Mungiu (1968), Corneliu Porumboiu (1975), Catalin Mitulescu (1972), Tudor Giurgiu (1972), Constantin Popescu (1973) o Radu Muntean (1971). Una generación que coincide en cierta medida con la «generación del decreto», esto es, nacidos después del decreto contra el aborto promulgado por Ceausescu en 1966; y la misma generación que tuvo un papel más activo en las transformaciones vividas por el país después de 1989, transformaciones que hay que considerar, en palabras de Doru Pop, «cinema-making included!»(Pop, 2014, 25). Este hecho desborda los datos biográficos para situar a estos jóvenes en un horizonte histórico compartido, justo en un momento en que el país vivía un período de cambios y de turbulencias sociales y políticas. A esto se une una formación común en la Universidad Nacional de Teatro y Cine Ion Luca Caragiale, a excepción de Puiu, así como un plantel actoral y un equipo técnico compartido.

En cuanto a la producción, se trata por lo general de proyectos con un bajo presupuesto y financiados, en su mayor parte, por sus propias compañías. La primera empresa privada dedicada a la producción cinematográfica tras la caída del régimen comunista fue Filmex, fundada en 1991 por Constantin Popescu. Por su parte, Tudor Giurgiu fundó Libra Film en 1994, con una clara vocación internacional. En 2004, Corneliu Pormboiu fundó $42 \mathrm{Km}$ Film en Vaslui, su ciudad natal, como forma de mantener su autonomía creativa. De otra parte, Cristian Mungiu dio vida a Mobra Films, desde la que ha producido sus propias películas, así como las de algunos de sus colegas. Un año después, junto a Hanno Hoffer y Oleg Mutu, Cristi Puiu funda la productora Mandragora, desde la que ha concebido sus propias películas.

También a nivel institucional se produjeron una serie de cambios que impulsaron la reactivación de una industria que llevaba una década generando muy pocos proyectos, en gran medida dependientes de las coproducciones extranjeras. En el año 2000 la Oficina Nacional de Cine pasó a ser el Centro Nacional de Cinematografía (CNC), dependiente del Ministerio de Cultura, desde el que se concretaron nuevas líneas de financiación; las cuales se ampliaron en 2002 con una ley que extendía el concurso de guiones a los cortometrajes. Las ayudas a la financiación ascendieron al 49\% del presupuesto, si bien el criterio seguía favoreciendo a la vieja guardia, como es el caso de Nicolaescu (Nasta, 2013, 149). Estas medidas, que promovieron la reactivación de la industria cinematográfica rumana, se sitúan cronológicamente en el arranque del cine rumano reciente. Además, estas producciones se han beneficiado de iniciativas públicas y privadas de diferentes instituciones europeas destinadas a potenciar el cine europeo, como el Berlinale Talent Campus, la Cannes Cinéfoundation, MediaPro Studios o el Rotterdam $\mathrm{Hu}-$ bert Bals Fund.

Por lo tanto, si prestamos atención a los cuatro criterios señalados por Higson (1989), advertimos, de acuerdo con lo anterior, coincidencias idiomáticas, de producción, de financiación y de distribución. Asimismo, es reseñable la identificación de un interés común por revisar la situación presente y pasada del país para cuestionar y abrir nuevas vías en la noción de nacionalidad, y confrontarlas al relato dominante. Respecto de la respuesta crítica, esta ha sido indudable. Así, además de los trabajos que reseñamos en nuestro estudio, se han editado especiales en publicaciones especializadas como Cabiers du Cinéma, Sight and Sound, Film Comment, Positif o Caimán cuadernos de cine. Al respecto, resulta revelador que el número de enero de 2007 de la revista francesa Positif se abriera con un especial dedicado al «cine rumano», en el que la única referencia a una «nueva ola» surgía de boca de los propios realizadores en una mesa redonda en la que participaban Radu Mihaileanu, Radu Muntean y Corneliu Porumboiu (Martinez, 16). A finales de ese mismo año, el éxito en el Festival de Cannes de 4 meses, 3 semanas y 2 días, refrendado por decenas de premios en festivales de todo el mundo, daría carta de legitimidad a la «nueva ola rumana». 
El interés por este cine ha ido creciendo en los medios, en los estudios académicos, en las filmotecas y en los festivales, donde ha continuado cosechando premios. Mientras tanto, parte del debate se centraba en la distinción conceptual entre «Nueva ola del cine rumano» (la opción elegida por Doru Pop para su libro) y «Nuevo cine rumano». La monografía de Dominique Nasta opta por una opción más neutra, «Cine rumano contemporáneo», dado que estudia el cine rumano de varias generaciones de realizadores; mientras que, cuando habla del cine de Puiu, Mungiu, Porumboiu o Muntean, recurre al término «nueva ola». La más reciente publicación de la Universidad de Edimburgo aborda el tema bajo el título The New Romanian Cinema (Stojanova, 2019), dado que incluye el cine más reciente de Pintilie y Caranfil, pertenecientes a generaciones anteriores. Las implicaciones de utilizar un término u otro tienen que ver con las relaciones que se establezcan con la nueva ola francesa, con los nuevos cines de los años sesenta y con el valor que se le otorgue a la aportación rumana a dichos cines. En este apartado, hay que tener en cuenta sobre todo que hablar de «cine rumano contemporáneo» excluye la posibilidad de pensar la existencia de una corriente distintiva dentro de un abanico tan amplio. El investigador Doru Pop propone el término «New New Wave», para distinguirlo de la «Old New Wave» (Pop, 2014, 23), aunque, a continuación, lo desecha.

Por nuestra parte, dudamos de la funcionalidad de un término como «nueva nueva ola», y nos inclinamos, en razón de lo expuesto, por el término «Nueva ola del cine rumano». Razonemos, a continuación, esta elección conceptual, tomando como referencia los criterios propuestos por Higson que hemos expuesto en este mismo apartado.

La reacción de la crítica demuestra que el fenómeno tomó cuerpo en los festivales de cine europeos, sobre todo en Cannes y Berlín, donde desde 2001 a 2008 se fue dando valor a esta cinematografía, que había sido impulsada, a su vez, por cambios administrativos en su país, por unas favorables condiciones de producción, por el respaldo de la crítica, por el ánimo común de unos cineastas que compartían similares vivencias e inquietudes, así como en la participación económica de instituciones públicas y privadas europeas. Este cine emerge, además, en un entorno europeo convulso, marcado por los ensayos de un nuevo orden mundial, la desigualdad, las migraciones, el desánimo ciudadano y la virtualización del entorno social.

A estos efectos, la repercusión lograda por este cine, aunque escasa dentro de Rumanía, lo distingue del «viejo nuevo cine rumano», y lo sitúa en un plano similar al de las «nuevas olas» que arriban a las costas de Cannes cada vez que se descubre una nueva cinematografía; con lo que el «nuevo cine rumano» referiría las producciones que se dieron en la década de los 60 en sintonía con los llamados «Nuevos cines». Por lo tanto, esta «nueva ola del cine rumano» inunda las pantallas europeas, y mundiales, con el nuevo siglo y con la potencia liberadora de aquellas personas que han atravesado un periodo de oscuridad y confían al poder de la memoria, las imágenes y las narraciones la posibilidad de un cambio social, de nuevas formas de pensar(se).

Siguiendo con los criterios propuestos por Higson, faltaría atender los aspectos relacionados la influencia cultural, en relación a otros modelos, y la aproximación textual al mismo: estilo, temas, carácter nacional, conciencia del espectador. En los siguientes apartados procederemos a examinar, desde la perspectiva metodológica del análisis textual, un conjunto de películas producidas en la primera década del siglo XX, y que fueron dando forma a lo que se conocería como la «nueva ola del cine rumano», con el fin de determinar la confluencia o no de unos rasgos estilísticos y narratológicos compartidos. En esta selección, tomamos como eje vertebrador la obra de los tres realizadores más relevantes de este movimiento: Crisi Puiu, Crisitan Mungiu y Corneliu Porumboiu.

\section{Cristi Puiu y las diferentes vertientes del joven cine rumano}

La primera película que capta la atención internacional y que certifica esta etiqueta cinematográfica es La muerte del señor Lazarescu (Cristi Puiu, 2005), todo y que 
Bienes y dinero (Marfa si banii, Cristi Puiu, 2001) es considerado el primer «building block» de la nueva ola del cine rumano (Pop, 2014, 3). Como apunta Nasta en otro texto, los más reputados críticos y teóricos rumanos consideran que «the trendsetting origins of the New Romanian Cinema pioneering aesthetic revolution are to be found» en las dos primeras películas de Puiu (2019, 24).

El argumento de Bienes y dinero nos sitúa en un entorno marginal, suburbano, protagonizado por personajes anónimos que se enfrentan a las vicisitudes del día a día, y cuyas preocupaciones se proyectan sobre el fondo de una Rumanía en plena transición, y en la que se dejan sentir las huellas del pasado reciente. El joven protagonista ansía desprenderse de la herencia familiar y labrarse un futuro propio, pero lo quiere hacer por la vía rápida, recurriendo a métodos corruptos, lo que le llevará a una toma de conciencia moral sobre las consecuencias de sus decisiones. Todo ello es narrado por una figura enunciativa que rehúsa el poder demiúrgico sobre el relato para situarse junto a los personajes, para privilegiar una mirada observacional sobre sus actos, gestionando la misma información que ostentan los personajes, y tratando de lograr el reconocimiento de una realidad concreta. El uso de la cámara al hombro, así como la ausencia de contraplanos de la mirada de los personajes, de música extradiegética, de motivaciones de carácter psicológico que impulsen la acción, de planos analíticos que no están justificados por los movimientos de los personajes; y todo ello unido a la presencia de tiempo muertos o de fragmentos de carácter meramente descriptivo, van encaminados a inscribir en las imágenes un efecto de realidad, una representación reveladora de la misma que el espectador logre identificar y en la que pueda reconocerse. La figura del viaje queda inscrita, a su vez, como la proyección de la necesidad de salir de una situación de bloqueo, para alcanzar el tan deseado progreso; así como la figuración simbólica de la situación de estancamiento que vive la sociedad rumana, en la que las tan ansiadas reformas democráticas no terminan de materializarse y las prácticas corruptas han alcanzado un nivel estructural.

El retrato de una Rumanía en la que los ensayos del modelo capitalista conviven con los reflejos heredados tras décadas de sistema represivo se plasma también en Cigarettes and Coffee (2004), el siguiente cortometraje de Puiu. Estas dos dimensiones sociales son sugeridas, además de quedar plasmadas en la brecha generacional que deriva de la relación de un padre y un hijo que se reúnen en un restaurante, por la puesta en escena, que demarca el espacio exterior (el del padre) y el interior (el del hijo) por medio de un ventanal enmarcado por unas cortinas. Resulta significativo la manera en que la disposición de los elementos de la puesta en escena hace de la ventana sobre la que se proyectan los protagonistas una especie de pantalla, un lugar de pensamiento que «se abre a un devenir, un 'por construir'» (Comolli, 29), y que vuelve evidente el dispositivo cinematográfico (Fotograma 1).

\section{Fotograma 1. Cigarettes and Coffee}

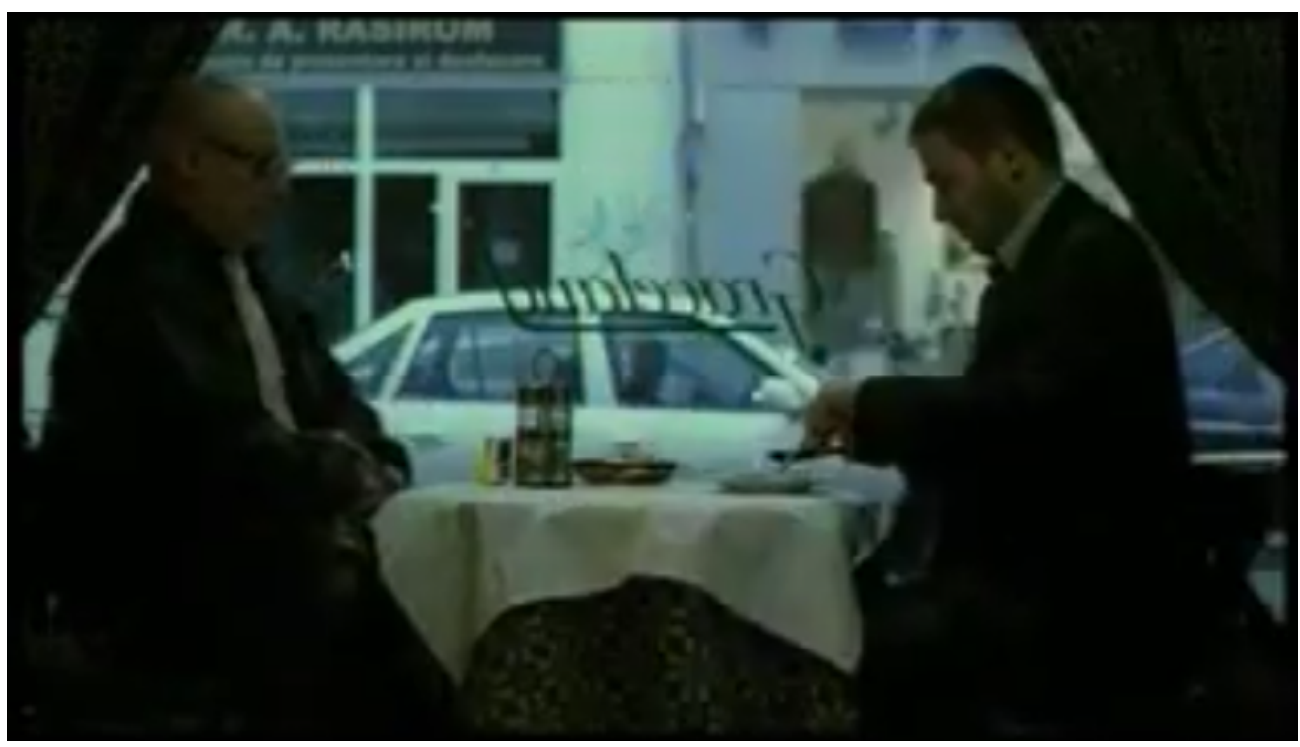


A diferencia de la idea del cine como ventana abierta al mundo, ese abrirse al mundo de manera transparente del Modelo de Representación Institucional, esta composición advierte de la cualidad construida de la realidad. Un planteamiento este que constituye el sustrato teórico de La reconstrucción (Lucian Pintilie, 1968). Además, y al igual que ocurría en la película de Pintilie, este enfoque reflexivo se completa con el empleo del humor absurdo, que conlleva un desplazamiento de sentido que desactiva los convencionalismos y los lugares comunes. Este será también el enfoque que caracterice La muerte del señor Lazarescu. Además, en las cuatro películas se da una comprensión del tiempo dramático en unas pocas horas o en varios días de la vida de los personajes, componiendo un fragmento de vida que queda inconcluso, merced a una resolución abierta. Esto supone la concatenación lineal de las acciones, de tal manera que los cortes se vuelven imperceptibles para favorecer la impresión de que los acontecimientos se suceden en tiempo real.

Algunas de las propuestas formales señaladas en las películas anteriores, en especial aquellas que desde la puesta en escena reproducen las condiciones represivas que perviven en la Rumanía actual y las que revelan el dispositivo, son llevadas al límite en Aurora, un asesino muy común (Aurora, Cristi Puiu, 2010), hasta componer

Fotograma 2. Aurora, un asesino muy común

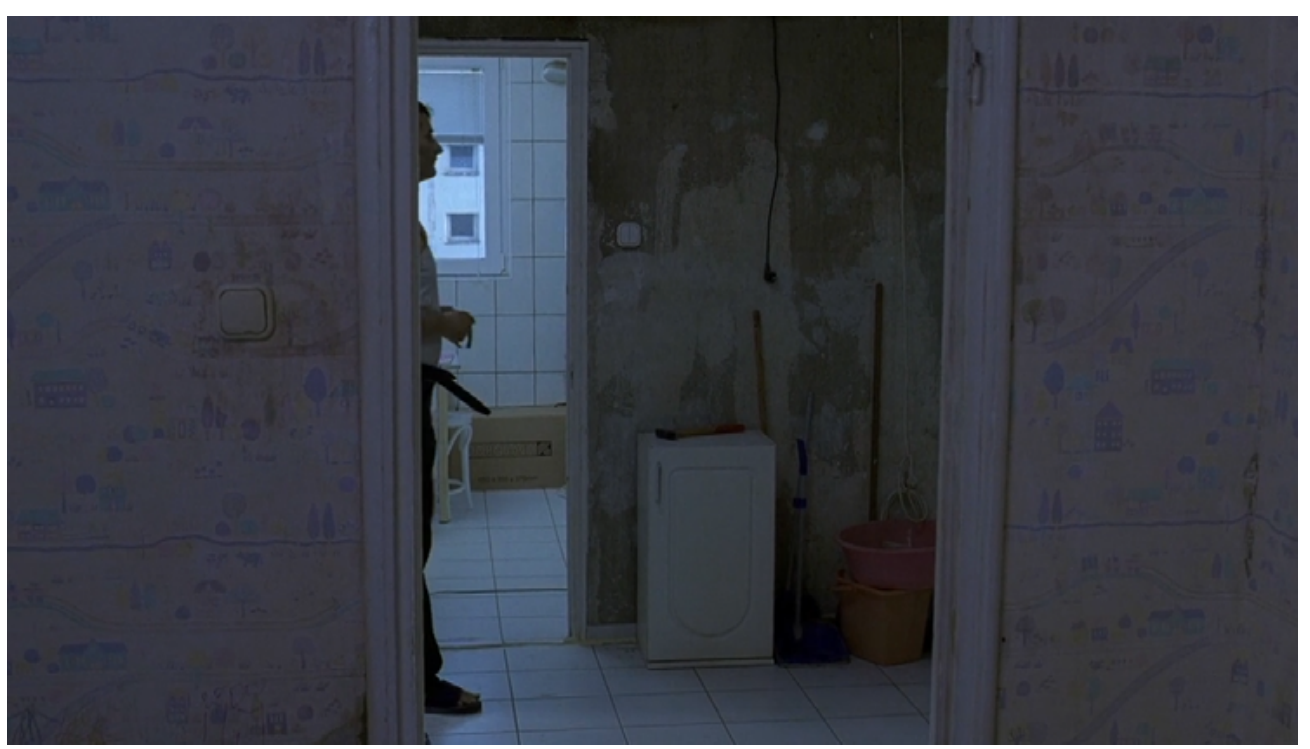

un relato fragmentario, hermético, el cual nos vemos obligados a descifrar a partir de unas escasas pistas, de pequeños indicios. Nuestro análisis nos ha permitido apreciar cómo desde la puesta en escena se plantea una reflexión acerca de los límites implícitos en cualquier análisis de la realidad, también al nivel de los procedimientos cinematográficos. La presencia constante de elementos físicos que se interponen entre la cámara y los acontecimientos que son narrados así lo determinan, al tiempo que evidencian el dispositivo de vigilancia estructural que pervive al cambio de régimen experimentado por el país (Fotograma 2).

Asimismo, estos mecanismos narrativos y visuales se corresponden con una voz enunciativa manifiesta, que expresa la voluntad de enunciarse a sí misma. Las estructuras cerradas que demarcan los marcos de las puertas y las composiciones en abismo refuerzan esta toma de posición política y estética que comprende la provisionalidad de cualquier verdad sobre el mundo, así como las mediaciones que intervienen en la búsqueda de dicha verdad; a la par que implican a un espectador que en todo momento es consciente de su condición de observador activo.

Todo y que las primeras películas de Puiu concentran gran parte de las claves argumentales y estilísticas atribuidas al cine que estudiamos, no en vano, el crítico de cine Alex Leo Serban acuñó la categoría ACP (After Cristi Puiu) para referirse a las producciones rumanas posteriores a La muerte del señor Lazarescu (2005) (Nasta, 2013, 162-163); un análisis más atento a la obra de otros directores incluidos en esta corriente cinematográfica nos permitirá apreciar otras vertientes formales.

El mismo año de producción de Bienes y dinero se presentaba Popcorn Story (Tu- 
dor Giurgiu, 2001), un cortometraje que se instala en un espacio extraterritorial ya apuntado por el idioma elegido par el título, para componer un artefacto ecléctico, extravagante, posmoderno, que se complementa con las emociones que vehiculan temas musicales de sobra conocidos. La ausencia de diálogos, los insólitos tiros de cámara, las luces de neón, los colores saturados, la extravagancia de la decoración y el vestuario, la aceleración de la imagen como efecto cómico, los gags sonoros o el empleo de música electrónica componen una obra heterogénea que celebra la fascinación de las tecnologías audiovisuales, como el cine, y cuya estilización formal la emparenta con el cine de Jean-Pierre Jeunet o con el discurso publicitario.

Esta misma estética impregna algunas partes del primer largometraje dirigido por Giurgiu en 2006, Love Sick (Legaturi bolnavicioase), que presenta un triángulo amoroso en el que se ven implicadas dos chicas adolescentes y el hermano de una de ellas. Apreciamos cómo la continua fragmentación del espacio y del punto de vista, el empleo de una música extradiegética proveniente del mercado del pop, que refuerza el plano sentimental tratando de seducir al espectador, y con un argumento que se desarrolla a lo largo de más de un año, componen un drama sentimental entre dos mujeres que privilegia el componente emocional sobre el reflexivo. Aquí no identificamos ninguna de las formas que hemos señalado en el caso de Puiu, las cuales se aplican en figurar los dispositivos de control y de visión que organizan tanto la vida de los personajes como la propia representación, y que ahondan en los diferentes modos de pensar el presente y el pasado de una Rumanía en permanente estado de transición. De lo que deducimos que estas dos obras dirigidas por Tudor Giurgiu, a quien Doru Pop considera uno de los realizadores más importantes de esta «nueva ola» $(2014,210)$, se sitúan en una órbita estilística distinta a la que proyectan las primeras producciones de Puiu. La línea que traza esta vertiente transversal, recorrida por múltiples y diversas influencias, y que se aplica en dotar a la imagen de un mayor atractivo visual, se puede rastrear en las primeras películas de Cristian Mungiu, como Zapping (2000) y Occidente (2002).

\section{Cristian Mungiu y la posible consolidación de una marca común}

El cortometraje Zapping (Cristian Mungiu, 2000) tiene como clara protagonista a la televisión, como vehículo de alienación y como instrumento de control en manos del poder. En esta obra primeriza se dan cita códigos propios del fantástico, el terror, la crónica costumbrista o la crítica social, combinados con citas fácilmente reconocibles, como en el caso de Taxi Driver (M. Scorsese, 1976); y todo ello envuelto en un tono general de parodia. Esta mirada desencantada e irónica sobre la sociedad rumana se vuelve a plantear en Occidente (Occident, Cristian Mungiu, 2002), en la que partiendo de una estructura de historias cruzadas se aborda el tema de la emigración. Al igual que ocurre en Zapping, el foco se emplaza en las vivencias cotidianas de unos personajes comunes que viven en un entorno marginal. El tono desencantado del que hablamos se resume en la decepción que viven los personajes al no ver cumplidas las expectativas que prometía el cambio de régimen, con lo que la solución más factible es emigrar a otro país siguiendo la estela de un Occidente idealizado. Por otro lado, el plano de situación (un bloque comunista del extrarradio) ancla la historia en un espacio en el que se dejan sentir las huellas del pasado y en el que los personajes andan perdidos en una época dramática y confusa, una realidad multiforme sobre la que se vuelve necesario reflexionar cuanto antes. También en este caso nos encontramos con una comedia rica en matices, en la que la mezcla del elemento mágico, la irrupción de la sorpresa, el gag, el tono onírico, la multiplicación del punto de vista, las citas cinéfilas (como ocurre con Pulp Fiction (Quentin Tarantino, 1994)) o la elección de los temas musicales, contribuye a dotar al conjunto de un tono excéntrico y resolutivo.

Otro ejemplo de la diversidad estilística que señalamos es la particular poética desarrollada por Cristian Nemescu en su escasa cinematografía, caracterizada 
por su eclecticismo y atravesada por múltiples influencias, logrando componer una mirada personal en un universo ficcional que podemos identificar como «international art cinema»(Elsaesser, 498). Tanto el cortometraje C Block Story (Poveste de la scara C, C. Nemescu, 2003) como el mediometraje Marinela de la P7 (C. Nemescu, 2006) están habitados por personajes extraídos de la realidad del extrarradio, los patios traseros de los suburbios o de las zonas rurales. Se trata de niños y jóvenes que se enfrentan a los contratiempos cotidianos y al esfuerzo por sobrevivir en tiempos adversos con el impulso que generan los deseos sexuales. Este enfoque se proyecta sobre una realidad permeable a las recreaciones oníricas, a las incursiones fantásticas, a los cambios de registro y a las interferencias que conectan con el imaginario hollywoodiense. Desde la planificación y la puesta en escena se robustece este tejido heterogéneo al aplicar a un contexto realista registros variados procedentes del Dogma 95, el fantástico, el melodrama, la crónica costumbrista, la comedia sentimental o la crítica social; y donde se dan cita elementos textuales como los jump cuts, los movimientos de grúa, los travellings de seguimiento, la pantalla partida, la música extradiegética, la cámara lenta, el tratamiento espectacular de las acciones, la estilización fotográfica, los tiros de cámara inauditos o la estructura no lineal de la narración.

Así las cosas, y antes del estreno de 4 meses, 3 semanas y 2 días (Cristian Mungiu, 2007), que fue el detonante que terminó de certificar el surgimiento de esta «nueva ola», nos encontramos con un conjunto de películas fruto de una serie de cambios técnicos, educativos, sociales, de condiciones de producción e ideológicos, que destacan por su energía creativa y por abordar la realidad rumana del nuevo siglo con formas nuevas, que se distinguen del cine de las décadas precedentes. El trabajo de este grupo de nuevos talentos va a lograr llamar la atención de los principales festivales de cine europeos. De tal manera que el éxito internacional logrado por $L a$ muerte del señor Lazarescu (2005) va a aglutinar en torno a esta película, y a sus particularidades narrativas y formales, a esta nueva cinematografía surgida de un país sin apenas presencia en los escaparates del cine mundial. Sin embargo, el análisis fílmico aplicado a estas obras nos permite apreciar la variedad de propuestas estéticas y temáticas que contienen.

Es en razón de esta doble vertiente perfilada en nuestro análisis, atenta a la singularidad de las obras, que se vuelve obligado repensar el fenómeno surgido a raíz del éxito obtenido por 4 meses, 3 semanas y 2 dias en el Festival de Cannes de 2007. Teniendo en cuenta, además, que en ese mismo certamen fue premiado el primer y único largometraje dirigido por Nemescu, California Dreamin' (2007). En efecto, observamos que algunos de los rasgos más significativos atribuidos a esta nueva ola, que parecía confirmarse con el segundo largometraje dirigido por Mungiu -largos planos fijos (el uso de la cámara al hombro, uno de los principales rasgos atribuidos a este movimiento, no se da en esta película), desarrollo temporal en un día o unas horas, ausencia de música extradiegética, linealidad, uso del plano secuencia (Scott, 2008a; Nasta, 2013; Pop, 2014) o minimalismo (Stojanova, 2019)- no son en modo alguno atribuibles a la película dirigida por Nemescu.

Existen más diferencias a tener en cuenta respecto de estas dos películas presentadas en 2007. Respecto de los recursos narrativos, si bien ambas películas están inspiradas en hechos y personas reales, el enfoque adoptado en cada caso es del todo opuesto. Mientras que 4 meses, 3 semanas y 2 días se desarrolla a partir del punto de vista de la protagonista principal, Otilia, a quien la cámara sigue en todo momento, de manera que accedemos a la información al mismo tiempo que la protagonista; California Dreamin' constituye una obra coral conducida por un narrador omnisciente que organiza todo el relato, incluyendo saltos en el tiempo, y que gestiona todo el saber. En ambas se evita recurrir al happy end convencional, aunque, así como 4 meses, 3 semanas y 2 días da comienzo in media res y termina de forma abrupta con la mirada a cámara de la protagonista, la película de Nemescu compone un final que es apoyado por una explicación que enmarca los acontecimientos mostrados en el contexto de la Guerra de 


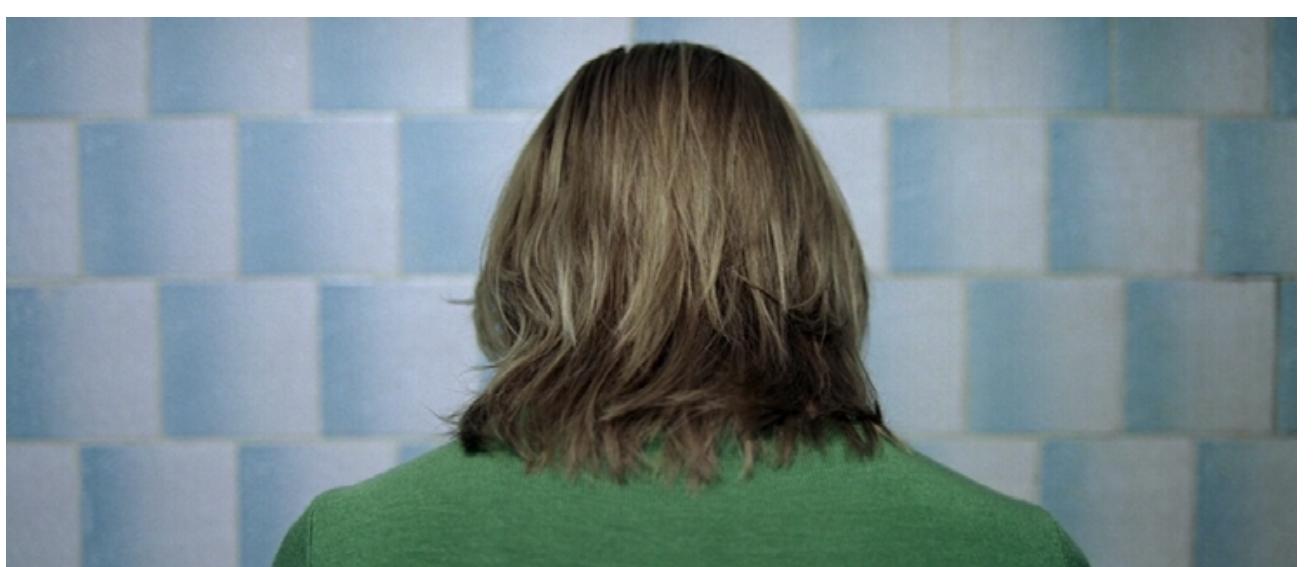

Fotograma 3.4 meses, 3 semanas y 2 días cuestión a unos cuantos elementos: uso de la cámara en mano, búsqueda de la «verdad», neorrealismo, narración en tiempo real, austeridad formal o situaciones cotidianas. Con lo que, en ausencia de un análisis textual atento a las formas cinematográficas y a las operaciones de sentido que vehiculan, estos trazos devienen meras carcasas conceptuales.
Yugoslavia, e incluye un epílogo que abre la vía a una posible solución de continuidad a la relación sentimental de la pareja protagonista. Con todo, la diferencia más reseñable reside en las formas en que el sujeto espectatorial es implicado en la película de Mungiu (incluyendo la vulneración de la cuarta pared), y el modo en que la composición de los encuadres reproduce el estado de ánimo de las protagonistas y las condiciones de existencia que las rodean; de manera que los elementos de la puesta en escena se cargan de una especial significación (Fotograma 3). Estas formas, en las que destacan las líneas verticales que cercan, los espacios cerrados, los largos pasillos laberínticos, la presencia de ventanas, las composiciones en abismo y el modo en que en todas ellas se deja sentir la pregnancia del fuera de campo, son las que estimamos más reseñables en algunos de los filmes que estudiamos.

Por lo tanto, igual que ocurría en el caso de La muerte del señor Lazarescu, la repercusión mundial alcanzada por 4 meses, 3 semanas y 2 días va a provocar la asimilación de la etiqueta «Nueva ola del cine rumano» a una parte de las propuestas, eclipsando al resto. Tampoco ayudó en este sentido el hecho de que la mayoría de aproximaciones teóricas a este fenómeno se centraran en los aspectos temáticos, destacando la mirada «realista» que se proyectaba sobre una sociedad de la que apenas se sabía nada, o que se aplicara el mínimo común denominador para reducir la complejidad de la

\section{Corneliu Porumboiu y las distintas representaciones de la Revolución rumana}

En los primeros trabajos de Corneliu Porumboiu, como los cortometrajes Gone with the Wine (Pe aripile vinului, 2002) y Viaje a la ciudad (Calatorie la oras, 2003), se dan algunos rasgos que vale la pena remarcar: la preocupación por los problemas que aquejan a las personas que se sitúan en los márgenes de la sociedad, el humor absurdo, la disparidad generacional, la corrupción sistémica, la falta de oportunidades, el desplazamiento del campo a la ciudad, la salida del país como única vía de escape a las penurias, el desencanto resultante de no lograr aquello que se buscaba y la puesta en escena de un presente que se confunde con el escenario de tiempos pasados. Además, como ocurría en La reconstrucción ( $\mathrm{Lu}-$ cian Pintilie, 1968), las actitudes honestas que se dan en el interior de un sistema injusto resaltan, por contraste, los aspectos más humanos de los personajes que las poseen, quienes, al final, acaban pagando por ello.

De sus primeras producciones destaca el mediometraje El sueño de Liviu (Visul lui Liviu, 2004), en el que, a diferencia de las películas dirigidas por Puiu que hemos analizado, el pasado socialista no deriva únicamente de la puesta en escena, sino que es expuesto de manera explícita con la inclusión de unas imágenes de archivo 
en la apertura del filme. De esta forma, el hecho real se inscribe como desencadenante de la ficción a partir de unos hechos históricos cuya repercusión se pretende destacar. En este sentido, el archivo, que se ofrece como legitimación histórica del relato a que da pie, funciona como «una puesta en abismo de re-mediaciones» (Carrera y Talens, 144). En consonancia con los dos cortometrajes reseñados al inicio de este apartado, la relación causa-efecto entre el discurso político de Ceausescu que abre el prólogo y el presente de una Rumanía estancada en el barro de corrientes pasadas o, en un sentido más amplio, entre las decisiones del pasado y las respuestas del presente, no desemboca en una conclusión tranquilizadora; por el contrario, se abre a la posibilidad de una idea, a un espectro de interpretación, a una reconstrucción simbólica del pasado que ilumine el presente. Esta búsqueda es planteada por medio de un dispositivo enunciativo y unos estilemas que dan como resultado un espacio simbólico abierto a nuevas expectativas, que «sirve para diferenciar lo que siempre se ve de lo que siempre se tiene que buscan» (Metz, 258). Esta película indaga en la historia del país interrogándose acerca de los modos de representación desde los cuales pensar sobre la misma, de su pertinencia y de sus límites, asumiendo el carácter irreductible de lo real y la tensión permanente que se inscribe entre los acontecimientos históricos y su representación. Si hay un acontecimiento histórico que articula estas películas, ese es la Revolución de 1989, una revolución televisada que centrará, cuestionando su naturaleza, así como los modos de recepción y los dispositivos de representación de la misma, el primer largometraje de Porumboiu, 12:08 al este de Bucarest (A fost sau n-a fost?, 2006).

No existe un consenso a la hora de nombrar o de explicar lo que ocurrió en Rumanía a finales de ese año tan determinante. Tras citar las declaraciones del sobrino del dictador, quien ve «un golpe del Estado soviético» detrás de estos acontecimientos, el analista político Robert D. Kaplan reconoce cierta influencia rusa en la desconfianza hacia los dirigentes rumanos, pero insiste en que «el levantamiento sí fue un acontecimiento populan» (163). En su investigación, Alice Bardan analiza cómo lo que en un inicio fue visto por televisión como una revolución, más tarde ha sido considerado por los analistas como un golpe de estado. Dentro de la esfera pública rumana, Bardan describe cómo el argumentario de las élites ha ido dirigido a dotar de autoridad a una perspectiva específica, con unos procedimientos discursivos concretos, que aseguren «the recognition of the Romanian 'revolution' as revolution, and therefore, as a true meaningful 'object' of commemoration» (Bardan, 131). Tal como explica Bardan, este debate se ha extendido a la educación, en concreto a la explicación que de los acontecimientos se hace en los libros de texto, a los medios de comunicación en general, y a los debates televisivos en particular.

Curiosamente, el mismo año del estreno de 12:08 al este de Bucarest (C. Porumboiu, 2006) se estrenaron otras dos películas rumanas que contaban con la Revolución rumana como tema principal: Cómo celebré el fin del mundo (Cum mi-am petrecut sfarsitui lumii, Catalin Mitulescu) y El papel será azul (Hîrtia va fi albastrâ, Radu Muntean). Veamos las similitudes y diferencias entre estas tres películas.

La película dirigida por Mitulescu, Cómo celebré el fin del mundo, es la que más distancia toma respecto de los esquemas realistas para tratar de plasmar la fantasiosa visión del niño protagonista, optando por falsear la historia y hacer que sea este mismo el artífice de la caída de Ceausescu, a la manera de David contra Goliat. En cambio, en 12: 08 al este de Bucarest (C. Porumboiu, 2006) y El papel será azul (R. Muntean, 2006) se lleva a cabo una escritura en la que abundan los planos largos y los planos secuencia, en los que se deja sentir el modo en que el peso del tiempo afecta a los personajes en un entorno en el que los elementos de la puesta en escena se abren a la participación del espectador. Teniendo en cuenta, además, que el relato comprende únicamente unas pocas horas de tiempo diegético. Es en el interior de esta arquitectura formal, complementada con el humus de la tradición del absurdo, y en la que los subrayados emocionales, como la música extradiegética, están excluidos, donde cobran un inusitado valor significante las formas que cercan y abisman a los personajes; $y$, por 
ende, la mirada del espectador. Este mismo esquema será el que despliegue Porumboiu en su siguiente película, Policía, adjetivo (Police, adjective, 2009), dando forma a un complejo mecanismo de puesta en escena que pone de manifiesto las distintas formas en las que el dispositivo de control y vigilancia puesto en marcha por el régimen comunista pervive, junto con los recién estrenados anhelos democráticos, en una Rumanía en periodo de transición. De tal manera que las huellas del pasado están presentes no solo en el entorno arquitectónico, sino también en las pautas de comportamiento, en las conductas físicas, en el lenguaje, en la desconfianza entre ciudadanos, en las medidas legislativas; se trata de «un dispositivo que coacciona por el juego de la mirada; un aparato en el que las técnicas que permiten ver inducen efectos de poder» (Foucault, 2002, 175). Este clima opresivo es sugerido, además, por las formas que más destacamos en nuestro estudio: las estructuras que encierran, como los marcos de las puertas, los largos pasillos, la figuración del laberinto o las fronteras burocráticas.

Por el contrario, Cómo celebré el fin del mundo recurre a estrategias narrativas más convencionales, que se sirven de la elipsis o de la planificación para aportar vigor significante, y que se nutren de elementos fantásticos, de paisajes oníricos, de la carga emocional que aportan los temas musicales, de la ternura que desprenden los personajes singulares, de la comicidad de las situaciones o de la visión subjetiva de los pro- tagonistas. Esta propuesta, mucho más emocional que reflexiva, conecta con el carácter de películas como Zapping (C. Mungiu, 2000), Popcorn Story (T. Giurgiu, 2001), Occidente (C. Mungiu, 2002), C Block Story (C. Nemescu, 2003), Marinela de la P7 (C. Nemescu, 2006), Love Sicke (T. Giurgiu, 2006) o California Dreamin' (C. Nemescu, 2007).

En cambio, en 12:08 al este de Bucarest y en Elpapel será azul el lenguaje adquiere un rol preponderante, tanto a nivel de las relaciones personales y de las jerarquías de poder que se refuerzan por medio de los discursos orales y escritos, como en lo concerniente a las operaciones retóricas que dan cuerpo a la propia representación cinematográfica. La reflexión acerca de los límites del len- guaje en un mundo en el que la búsqueda de la verdad ha perdido todo sentido es propia de la tradición del teatro del absurdo. Lo que nos parece más significativo es el modo en que esta reflexión se traslada al propio mecanismo cinematográfico, a las estrategias estilísticas y los motivos significantes que vertebran la narración. Así, haciendo hincapié en el modo en que los discursos influyen en la representación colectiva del mundo, se sugiere la posibilidad de (re)construirlo permanentemente (Bordieu, 258-259). Es en este sentido en el que operan las formas cinematográficas que evidencian el dispositivo de visión, las estrategias discursivas que median en la comprensión del mundo, que cuestionan su propia eficacia y que reclaman una participación activa del espectador; y que hemos señalado en el caso de estas películas y en otras de directores como Puiu, Mungiu, y Porumboiu.

\section{Conclusiones}

Retomando el criterio especificado por Higson (1989) que nos faltaba detallar, relativo a las cuestiones textuales, podemos afirmar que la dimensión textual del corpus analizado, que se inserta en la «nueva ola del cine rumano», comprende un conjunto variado de poéticas singulares en las que es posible remarcar una serie de rasgos comunes, pero en el que se advierten notables diferencias formales que nosotros hemos identificado en dos vertientes claramente diferenciadas.

Apuntamos como principal rasgo común el hecho de que las historias se desarrollen en entornos marginales, bien en los suburbios de la capital o en zonas rurales, habitados por personajes comunes que se conducen de manera naturalista por espacios reales y que se expresan por medio de diálogos carentes de afectación. Además, por lo general (aquí la excepción la compondrían La muerte del señor Lazarescu y 12:08 al este de Bucarest), están protagonizadas por jóvenes que encarnan a una generación similar a la de los realizadores, que han vivido el cambio de régimen y que encaran el futuro con unas preocupaciones diferentes a las de sus pa- 
dres. Este carácter generacional se aplica en visibilizar una(s) realidad(es) que había(n) permanecido ausente en el cine rumano de las décadas anteriores, ampliando los límites de lo decible, el verosímil cinematográfico; y sirviéndose para ello de la impresión de inmediatez, espontaneidad y cercanía que proporcionan las representaciones realistas. La adopción de esta perspectiva sobre la realidad implica un compromiso ético que lleva a la necesidad de construir una memoria colectiva que comprenda los problemas asociados a las clases desfavorecidas, y una actitud sensible respecto de las injusticias sociales. A su vez, este compromiso con las pequeñas historias, con los episodios cotidianos, persigue una «toma de conciencia» por parte del espectador, para que se sienta integrado y comprometido «con esa realidad mediante la ficción organizada» (Monterde, 148-149), para que empatice con esos antihéroes que, como ocurría con los que habitaban las ficciones neorrealistas y las de los nuevos cines, no se conducen por unas férreas motivaciones psicológicas, como ocurría en el MRI, sino que se aprestan a sobrevivir en un entorno que les es adverso y que no acaban de comprender, valiéndose para ello de un rasgo constitutivo del carácter rumano como es el humor.

Advertimos, asimismo, unos temas comunes, como el desplazamiento del campo a la ciudad, la emigración, los conflictos generacionales, la Revolución rumana de 1989, la corrupción sistémica, el carácter transgresor de la pulsión sexual, la ausencia de una autoridad legítima, la falta de expectativas o el modo en que las prácticas estructurales del periodo comunista se conjugan con los incipientes ensayos democráticos.

En cuanto a los recursos cinematográficos, prima la presencia de una mirada observacional que antepone la verosimilitud de los espacios a su descomposición en razón de unas determinaciones dramáticas y psicológicas, a la manera del MRI, que sigue los acontecimientos junto a los personajes, tratando de no juzgarlos ni de situarse por encima de ellos; es decir, accediendo a la información de los hechos al mismo tiempo que ellos, sin que se dé una lógica causal que los haga avanzar. Lo que nos lleva a una cuestión ya apuntada por Bazin y por Deleuze (1985) en relación al neorrealismo, la de la imagen-hecho, donde los hechos no están predeterminados por la forma, sino que son presentados en su propia materialidad: es debido a la reunión de unos hechos concretos y al carácter centrífugo de la imagen-hecho que se extrae un sentido final, «la moral de la historia» (Bazin, 310). De ahí que estas películas estén ausentes de soluciones conclusivas, de finales felices o de un abrochamiento de sentido que selle las diferentes tramas abiertas por el relato. Por lo demás, las diferencias formales son evidentes, y hay que comprenderlas también en las diferentes formas de pensar la cuestión de lo «nacional» en un momento de creciente fragmentación cultural, diversidad social y cambios políticos, cuando Rumanía se abría a un espacio globalizado persiguiendo una tan ansiada e idealizada imagen de Occidente.

En conclusión, asumiendo la ambigüedad esencial del término, y de acuerdo con lo expuesto anteriormente, la dimensión nacional de esta «nueva ola» se sustenta en similares condiciones relacionadas con la educación; la producción; las condiciones sociales y políticas; con ciertas afinidades temáticas, narrativas y formales; con la reacción contraria al cine rumano precedente y con un compromiso ético con la realidad del país. Si bien, y en relación a los criterios planteados por Higson (1989), no se puede hablar de una posible conciencia nacional compartida, ya que estas películas apenas contaron con una audiencia de 20.000 personas en su país. Pero, sobre todo, esta etiqueta adquiere pleno sentido como carta de presentación de cara al resto del mundo, que ha tomado forma en el Festival de Cannes, y que se ha visto refrendada con apoyos económicos por parte de instituciones públicas y privadas de Europa, con premios en los más renombrados festivales de cine, con números especiales en la prensa especializada, con estudios académicos y con exhibiciones en centros culturales de todo el mundo. Este es un buen momento para recordar que la etiqueta «Nueva ola del cine rumano» adquirió una entidad propia en 2007, tras el estreno mundial de 4 meses, 3 semanas y 2 días; precisamente, el año que se produjo la entrada de Rumanía en la Unión Europea. 
Ahora nos gustaría distinguir un conjunto de películas en las que confluyen una serie de formas cinematográficas que hemos destacado por su capacidad para implicar al espectador, para reactivar sus proyecciones imaginarias más allá de los límites del encuadre, y para proponer una reflexión acerca del lenguaje, también el cinematográfico, y de la relación que guarda con las diferentes formas de poder. Nos referimos a Bienes y dinero (C. Puiu, 2001), Cigarettes and Coffee (C. Puiu, 2005), La muerte del Sr. Lazarescu (C. Puiu, 2005), El sueño de Livin (C. Porumboiu, 2004), 12:08 al este de Bucarest (C. Porumboiu, 2006), 4 meses, 3 semanas y 2 días (C. Mungiu, 2007), El papel será azul (R. Muntean, 2006), Megatron (M. Crisan, 2008), Policía, adjetivo (C. Porumboiu, 2009), Morgen (M. Crisan, 2010) y Aurora (C. Puiu, 2010). En estas películas, las formas que cierran, los marcos de las puertas, las estructuras verticales, como los típicos bloques de vivienda soviéticos, o los largos pasillos que conforman un laberinto kafkiano reproducen las condiciones de existencia, el estado de ánimo y las circunstancias personales que envuelven a unos personajes que viven atrapados en una estructura social represiva, corrupta, estancada en una transición que no parece tener fin, en la que las buenas acciones merecen el castigo que se impone como norma y donde la única salida que se vislumbra es la huida del país. Esta formalización metafórica del encuadre cinematográfico se lleva a cabo sin explicitar la argumentación y sin plegar la puesta en escena al dictado demostrativo. Asimismo, las estructuras en abismo ponen en evidencia el dispositivo de filmación, el artificio que sostiene la representación y la arbitrariedad de las decisiones enunciativas.

En conclusión, estas formas cinematográficas que se cargan de significación asomadas a un abismo de significados, más que responder a un esquema realista, como de manera general se califica al cine que analizamos, «construyen realismos» (Castro de Paz, 157), conscientes del poder de la ficción para reproducir territorios expresivos en los que plantear interrogantes -ya que los textos fílmicos no solo representan la realidad; también la construyen, pues influyen en los modos de pensarla de otras formas-, para abrir espacios en crisis a través de los cuales construir una memoria colectiva, para hacer ver que todavía son posibles y deseables valores como la solidaridad y el compromiso que Otilia muestra a su mejor amiga en 4 meses, 3 semanas y 2 días: «Si la realidad es virtual, el arte puede ayudarnos a convertir la virtualidad -la fantasía de un mundo distinto, más justo- en una realidad» (Colaizzi, 165). Así es como estas formas despuntan en una Europa en la que valores como la dignidad humana cotizan a la baja, mientras la tecnificación y la virtualización de cualquier aspecto de la vida lleva a su mercantilización en las corrientes por las que circula el capital simbólico dominante. Unas formas que se insertan, a su vez, y clamando su condición enunciativa, en el Modo de Representación Europeo, ese espacio en el que el discurso se erige como un «espacio de poder» (Carrera, 137); una gran meseta hecha de mesetas, heterogénea, mutable, intercambiable, cuyos elementos se alteran de manera recíproca debido a las corrientes que los atraviesan, los socavan y aceleran; un territorio en el que el viajero no tiene miedo de perderse ni precisa de un principio y un final para orientarse, pues cuando llega al límite cae por un agujero que lo lleva a otro punto y vuelta a comenzar.

\section{Bibliografía}

Agamben, Giorgio. «¿Qué es un dispositivo?». Sociológica, mayo, 2011, no 33, pp. 249-264.

Ayuso Ros, Francisco. M. La puesta en crisis de la realidad. Politica y modos de representación en los nuevos cines en Europa: el caso de «La nueva ola del cine rumano» (20012010). Tesis doctoral, Universitat de València, 2021.

Bardan, Alice. «Aftereffects of 1989 Corneliu Porumboiu's 12:08 East of Bucharest (2006) and Romanian Cinema». En Anikó, Imre. A Companion to Eastern European Cinemas. New Jersey: John Wiley \& Sons, Inc, 2012, pp. 125-147.

Baudry, Jean-Louis. «Le dispositif: approches métapsychologiques de l'impression de réalité». Communications $\mathrm{n}^{\mathrm{o}} 23,1975$, pp. 56-72. 
Bergan, Ronald. «Romania's new wave is riding high». The Guardian, 25 de marzo, 2008. Recuperado de https://www.theguardian.com/film/filmblog/2008/mar/25/canroma- niasnewwavesustain Bordieu, Pierre. Cuestiones de sociología. Madrid: Ediciones Istmo.

Burch, Nöel. «Qu'est-ce que la Nouvelle Vague?». Film Quarterly, vol. 13 no ${ }^{\circ}$ 2, 1959, pp. 16-30.

Carrera, Pilar. «Un fantasma recorre Europa». Revista EU-topías, vol. 16, otoño, 2018, pp. 129-137.

Carrera, Pilar y Talens, Jenaro. El relato documental. Madrid: Cátedra, 2018.

Casetti, Francesco y Di Chio, Federico. Cómo analizar un film. Barcelona: Paidós, 1994.

Castro de Paz, José Luis. Formas en transición. Algunos filmes españoles del periodo 1973-1986. Barcelona: Shangrila Ediciones, 2019.

Colaizzi, Giulia. La pasión del significante. Madrid: Biblioteca Nueva, 2007.

Comolli, Jean-Louis. Cine contra espectáculo, seguido de, Técnica e ideología (1971-1972). Buenos Aires: Manantial, 2010.

Deleuze, Gilles. La imagen-tiempo. Estudios sobre cine 2. Barcelona: Paidós, 1985.

Elsaesser, Thomas. European Cinema. Face to Face with Hollywood. Amsterdam: Amsterdam University Press, 2005.

Fecé, J. L. «De la caméra stylo a la política de los autores. Los orígenes de una nueva cinefilia». En Heredero, C. F., Monterde J. E. En torno a la Nouvelle Vague. Rupturas y horizontes de la modernidad. Valencia: Institut Valencià de Cinematografia Ricardo Muñoz Suay, 2002, pp. 45-54.

Foucault, Michel. «El juego de Michel Foucault». En Foucault, M. Saber y verdad. Madrid: Ediciones La Piqueta, 1991, pp. 127-162.

Foucault, Michel. Vigilary castigar. Nacimiento de la prisión. Buenos Aires: Siglo XXI, 2002.

Higson, Andrew. «The Concept of National Cinema». Screen, volume 30, no 4, otoño, 1989, pp. 36-47.

Iglesias, Eulalia. «نUn nuevo cine rumano? Muchos premios, pocos directores, escasos estrenos». Cabiers $d u$ Cinéma España, no 8, 2008, pp. 8-25.
Istambul S. y Martínez, A. «El nuevo cine rumano o la pasión por la verdad». El genio maligno. Revista de humanidades y ciencias sociales, $\mathrm{n}^{\circ}$ 3, 2008, pp. 67-76.

Kaplan, R. D. A la sombra de Europa. Rumanía y el futuro del continente. Barcelona: El Hombre del Tres, 2017.

Martinez, Dominique. «Entretien avec Corneliu Porumboiu». Positif, número 551, enero, 2007, pp. 9-11.

Metz, Christian. Ensayos sobre la significación en el cine (1964-1968). Volumen I. Barcelona: Paidós, 2002.

Monterde, J. E. «Estrategias del realismo». En Peña Ardid, Carmen (coord.). Encuentros sobre literatura y cine. Zaragoza: Instituto de estudios turolenses, 1999, pp. 135-156.

Nasta, Dominique. Contemporary Romanian Cinema. The History of an Unexpected Miracle. New York: Wallflower Press, 2013.

Nasta, Dominique. «Beyond Modernity: The Stylistic Divide and the New Roma- nian Cinema». En Stojanova, Christina. The New Romanian Cinema. Edinburgh: Edin- burgh University Press, 2019, pp. 23-35.

Pena, Jaime. «Los caminos actuales de los 'nuevos cines' nacionales. El bosque y los árboles». Cabiers du Cinéma España, no 10 marzo, 2008, 12-13.

Pérez, Xavier. "Reinventar la ficción fílmica. La revolución temática”. En Heredero, C. F., Monterde J. E. En torno a la Nouvelle Vague. Rupturas y borizontes de la modernidad. Valencia: Institut Valencià de Cinematografia Ricardo Muñoz Suay, 2002, pp. 177-186.

Pop, Doru. "The Grammar of the New Romanian Cinema". Acta Univ. Sapientiae, Film and Media Studies, 3, 2010, pp. 19-40.

Pop, Doru. Romanian New Wave Cinema. An Introduction. Jefferson, North Carolina: McFarland \& Company, 2014.

Salvà, Nando. «Cristian Mungiu: 'A los rumanos, el sentido del humor nos mantuvo vivos». El Periódico, 19 de diciembre, 2010. Recuperado de https://www. elperiodico.com/es/ocio-y-cultura/20101219/cristian-mungiu-rumanos-sentido-humor-629982

Sardá, J. «Cristi Puiu: 'A los cineastas rumanos se nos recibió como monos que sabían hacer algo'». El Cultural, 31 de agosto, 2012. Recuperado de http://www. 
elcultural. com/noticias/cine/Cristi-Puiu-A-los-cineastas-rumanos-se-nos-recibio-como-monos- quesabian-hacer-algo/3661

Schaeffer, Pierre. Machines à communiquer. Tome II. Pouvoir et communication. París: Le Seuil, 1971.

Scott, A. O. «In film, the Romanian new wave has arrived». The New York Times, 2008a. Recuperado de https://www.nytimes.com/2008/01/19/arts/19ihtfromanian.1.9340722.html
Scott, A. «New wave on the black sea». The New York Times, 2008b. Recuperado de http: //www.nytimes. com/2008b/01/20/magazine/20Romanian-t.html?_r=1

Stojanova, Christina (ed.). The New Romanian Cinema. Edinburg: Edinburg University Press, 2019.

Stringer, Julian. «Global Cities and the International Film Festival Economy». En Shiel, Mark; Fitzmaurice, Tony (eds.). Cinema and the City: Film and Urban Societies in a Global Context. Oxford: Blackwell Publishers, 2001, pp. 134-144. 